\title{
Assisted Reproductive Techniques in Farm Animal - From Artificial Insemination to Nanobiotechnology
}

\author{
O P Verma*, R Kumar, A Kumar, S Chand \\ Indian Veterinary Research Institute, \\ Izatnagar - 243122, Dist. Bareilly (UP) India \\ * Corresponding author email: opvetivri83@rediffmail.com \\ Received: 01-10-2011, Accepted: 26-10-2011, Published Online: 11-02-2011 \\ doi: 10.5455/vetworld.2012.301-310
}

\begin{abstract}
It has become evident that advances in farm animal reproduction have become increasingly dependent on advance scientific research in addition to an understanding of the physiological processes involved in reproduction. The use of assisted reproductive techniques (ART) has helped owners to produce offspring from valuable farm animals that were considered infertile using standard breeding techniques. This chapter constitutes an update of recent developments in the field of assisted reproduction includes Artificial insemination, Embryo transfer, in vitro fertilization, embryo cryopreservation, Sexing of semen and embryos, cloning, transgenesis, stem cell technology, embryo genomics, micro and nanotechnology has been included. Recently in some of these fields remarkable progress has been made. None the less, imperfections are remaining and sustained efforts will be required to optimize existing and invent new technologies. Before referring an animal for an ART, the practitioner should be able to identify the underlying cause of subfertility of that animal. Knowing the complexity as well as the risks of these techniques, enables practitioners to refer a sub-fertile animal to the least complex and most appropriate and successful ART that can overcome specific causes of infertility.
\end{abstract}

KeyWords: Reproductive Techniques, Artificial Insemination, Nanobiotechnology, Embryo Transfer, Cryopreservation, Cloning, Transgenesis, Stem Cell Technology, Embryo Genomics.

To cite this article :

Verma OP, Kumar R, Kumar A and Chand S (2012) Assisted Reproductive Techniques in Farm Animal - From Artificial I nsemination to Nanobiotechnology, Vet. World. 5(5):301-310, doi: 10.5455/vetworld.2012.301-310

\section{Introduction}

Productivity is the key to growth and reproduction is backbone of animal production. Reproductive inefficiency is one of the most important causes of economic losses in animal industries and it is realized throughout the world. Despite of remarkable advancement that has been made in the field of reproductive physiology in recent years, infertility due to low conception rate and high embryonic mortality rate remains a major problem. To meet future needs and to be able to sustain agricultural production, agricultural research and its applications there is a need to use all emerging technologies especially the modern reproductive biotechnologies. Development of reproductive techniques like, estrussynchronization, super ovulation, non-surgical embryo collection, transfer, cryopreservation of embryos, oocytes pickup from live animals, in vitro maturation, fertilization, embryo development and cloning could not make an impact on quality animal production due to non availability of low cost embryos from quality animals. There is a scope for further improvement in reproductive status of our farm animals. The recent scientific developments in assisted reproductive techniques have made it possible to manipulate the reproductive processes in many ways to revolutionize world animal agriculture. In present review effort has been made to enrich the knowledge about various recent assisted reproductive techniques which may be helpful for improving the current status of livestock reproduction.

\section{Artificial insemination (AI)}

This technology has now become a practical technology in commercial dairy cattle programs in both developed and developmental countries. On historical point of view first successful insemination was performed by Spallanzani, (1784) in a bitch. Pioneering efforts to AI were begun in Russia in 1899 by Ivanow (Ivanoff, 1922). Ivanoff, (1922) had studied AI in domestic farm animals, dogs, foxes, rabbits, and poultry. Later on this technique was 
performed by various researchers worldwide in different species. Use of frozen semen (Polge et al., 1949) revolutionized the AI program through worldwide transport of semen. Initially artificial insemination (A.I.) was used to spread improved indigenous breeds which were followed by the introduction of crossbreeding. AI technology maximizes the use of outstanding males, dissemination of superior genetic material, improve the rate and efficiency of genetic selection, introduction of new genetic material by import of semen rather than live animals and thus, reducing the international transport costs, enabling the use of frozen semen even after the donor is dead; and, reduces the risk of spreading sexually transmitted diseases. Mostly AI is performed by utilizing the semen from exotic breeds and used in the expectation of increasing the production of local livestock populations. To a lesser extent, semen from local breeds is also used for this purpose. Various aspects of AI technology now a day have been fairly standardized.

In present scenario a large number of AIs are performed globally, more than 100 million cattle, 40 million pigs, 3.3 million sheep and 0.5 million goats are artificially inseminated every year (BoaAmponsem and Minozzi, 2006). Regarding to current status of AI in India, the production of frozen semen straw was 44 million and 41 million AI with $35 \%$ conception rate was achieved in year 2008 (Annual report, 2007-2008).

The conception rate in field AI programmes in developing countries is very low, and therefore the desired effect in terms of animal improvement has not been achieved. The reasons behind are lack of proper management and technical skill. AI will become more effective only when farmers will have access to considerably better technical and organisational facilities.

\section{IVM/IVF embryo production}

The potential for commercial production of genetically superior embryos by in vitro fertilization is apparent. In Past few decades there have been unprecedented evolution of technology for in vitro embryo production (IVEP) of embryos in farm animals, with the rate of progress getting intensified in the last decade with the characterization of effectively defined and semi defined medium for different species.

In vitro production technologies not only help in production of high genetic merit animals, but also provide an excellent source of embryos for emerging biotechnologies like embryo sexing, cloning, nuclear transfer, transgenesis etc. Furthermore, it allows analysing developmental potential of embryos, including the pattern of gene expression, epigenetic modifications and cytogenetic disorders during the development (Galli and Lazzari, 2008). Early stages of bovine embryo development show many similarities with human embryos. Therefore, bovine embryos are used as a model organism (Niemann and Wrenzycki, 2000).

Inspite of continuous efforts to improve bovine in vitro embryo production (IVP), its efficiency is still low, since only 30 to $40 \%$ blastocyst development has been obtained from oocytes after in vitro maturation, fertilization and embryo culture (Sirad et al., 2006). Despite of several advantages of in vitro embryo production, initial application in both cattle and buffaloes has been limited by the ability to recover oocytes. However, recent development of low invasive ultra sound guided transvaginal oocyte retrieval (TVOR) and oocyte pick up (OPU) has removed these difficulties to a large extent. Through OPU oocytes may be aspirated from live animals. Now OPU-IVEP is used in many countries for the large scale embryo production at commercial level. This repeated recovery permits production of more embryos than might be possible by standard ET practice (Galli and Lazzari, 2008). TVOR also allows repeated collection of oocytes from endangered species of livestock or livestock of high economic importance in order to propagate such genetic resources in much faster way. However, the practical use of IVEP is limited by high production costs and the low overall efficiency under field conditions.

\section{Intra cytoplasmic sperm injection (ICSI)}

Development of Intracytoplasmic sperm injection technique furnished a successful treatment for male infertility of different origin and has led to a resurgence of interest in its potential use in farm animal reproduction. In addition to its clinical usefulness, ICSI can be applied for the production of transgenic animal and to study the mechanism of fertilization.

Since the first report of ICSI success in hamster (Uehera and Yanagimachi, 1976) the transfer of embryo produced by ICSI has given rise to live young in rabbits, mice, sheep, humans, horses, cattle and pigs. ICSI is the micro-fertilization technique of the direct injection of a single spermatozoa or sperm head into ooplasm. This technique can further be used to extend the sperm vector system for transgenic animal production. The main indication for ICSI is severe 
male infertility due to various abnormalities of ejaculated spermatozoa, epididymal spermatozoa or testicular spermatozoa. ICSI has been performed in domestic species with variable success rate like 70 $80 \%$ in cattle (Horiuchi et al., 2002), 77\% in pig (Martin, 2000), and 48-63\% in small ruminants (Catt et al., 1996). In horses, IVF proved to be very complicated and problems-bearing procedure. Thus, intracytoplasmic sperm injection (ICSI) technique is preferably used for this species (Colleoni et al. 2007). Although fertilization rates with ICSI may be higher than IVF, pregnancy rates were poor $(<20 \%)$ as per various studies and no more effective in terms of clinical pregnancy rates than in vitro fertilization (IVF).

\section{Sexing of semen and embryos}

Predetermination of the sex of offspring would provide a greater number of males or females, which will help in selection of individuals with top genetic makeup for improvement in next generation (Plummer and Beckett, 2006). Known sex of embryos produced for use in ET programs can more effectively help to manage producer resources because more heifer calves per ET can be produced. The sexual differentiation of embryo is determined by the presence or absence of elements normally located on the Y chromosome. Some of the techniques employed commercially for the embryo sexing are: i) chromosomal analysis of demi embryos ii) immunological detection of embryonic $\mathrm{H}$ - $\mathrm{Y}$ antigen iii) use of Y-specific probes iv) Fluorescence in situ hybridization (iv) rapid sexing method for preimplantation embryos of bovine using Loop-Mediated Isothermal Amplification (LAMP) reaction (Zoheir and Allam, 2010). Another way is the sorting of semen, one sperm at a time, into males and females, using staining procedure and detecting by laser beam with the help of standard flow cytometry equipment (Garner, 2006).

Thus, sperms with $\mathrm{X}$ or $\mathrm{Y}$ chromosome could be used to produce female or male embryos. The bovine Y-chromosome specific sequences are conserved amongst buffalo, Indian zebu and Taurus cattle (Apparao et al., 1993). Thus, the use of bovine Ychromosome specific primers, demonstrate the sex of buffalo or Indian zebu cattle embryos. Efficient embryo biopsy method has also been developed (Lopatarova et al., 2008). It is a usual practice to extract one cell from an early embryonic stage and with the use of a DNA probe, embryos can be sexed. The high rate of survival and conception rates of biopsied embryos also reflects the minimal damage of the embryos during the process. In respect to the recent advances in semen sexing, using fluorescence activated cell sorter (FACS) offspring of predetermined sex have been successfully produced (Garner et al., 2008) using fresh and frozen-thawed spermatozoa in several mammalian species: cattle (Seidel et al., 1999), goat (Parrilla et al., 2004), pigs (Grossfeld et al., 2005) sheep (de Graaf et al., 2007).

Semen and embryo sexing have not been reported in the field in any of the developing countries, except China. At a research level, these technologies are being developed and refined in a number of research institutions in developing countries. The involvement of private companies providing these services is likely to increase their accessibility in developing countries where AI is already established.

\section{Oocyte/embryo cryopreservation}

Continuous availability of viable, developmentally competent oocytes has been critical to recent progress in IVEP because of the relatively short fertile life span of mammalian oocytes. Hence, storage of unfertilized oocytes would generate a readily available source, which allow the experiments to be carried out at convenient time and could therefore be of practical importance in the establishment of gamete bank from which particular genetic combinations could be derived. During the past few decades, significant progress in cryopreservation of mammalian oocytes and embryos has been achieved. Live offspring of at least 25 species resulted from transfer of cryopreserved embryos or oocytes (Gajda and Smor ${ }^{1} \mathrm{~g}$, 2009). Preservation of oocytes reduce the risk and expense involved in transport of live animals, hazards of disease transmission and also provides insurance against catastrophes and natural disasters. Preservation of oocytes in endangered species safeguards from danger of extinction. The major problem associated with cryopreservation of germplasm is mechanical as well as osmotic damage during processing steps. With the advent of glycerol as a cryoprotecting agent cryopreservation process became more feasible. Other CPs are also in widespread use, alone or in various combinations. These include permeating CPs such as ethylene glycol (EG) and propylene glycol (Chen et al., 2005, Luz et al., 2009) and non-permeating ones such as sucrose, glucose, or fructose (Barcelo-Fimbres $\&$ Seidel, 2007). With the development in traditional cryopreservation methods, vitrification of germplasm was introduced (Rall and Fahy, 1985). Vitrification is a simple, faster, less expensive technology than slow 
freezing. Moreover, it was shown to be more effective than slow freezing for material more sensitive to chilling (Vajta et al., 1996). Cryopreservation of oocytes by vitrification was attempted with variable success in bovine (Hochi et al., 2000), swine (Huang and Holtz, 2002), equine (Hurt et al., 2000) and buffalo (Sharma and Loganathasamy, 2006) oocytes. For vitrification various methods like EM grid, OPS, closed pulled straw, nylon mesh etc has been tried with more or less similar results.

Recently, high-security vitrification device (Camus et al. 2006), pipette tip (Sun et al., 2008), fiber plug (Muthukumar et al. 2008), vitrification spatula (Tsang \& Chow, 2009), Cryo-E (Petyim et al., 2009), sealed pulled straw (Yavin et al., 2009), plastic blade (Sugiyama et al., 2010), Vitri-Inga (Almodin et al., 2010), Cryopette (Portmann et al. 2010), and Rapid-i (Larman \& Gardner 2010) has been introduced with more convenient and better results. Freezing of embryo is an established commercial practice and the major aim of it is to preserve the embryo in a viable condition from which it may be revived to continue a normal development. Embryo freezing is an essential component in the commercial ET programmes as there is an obvious need to store the embryos on temporary basis until they are transferred, as the embryo viability starts to decline after $12 \mathrm{~h}$ of storage in holding media. With regard to the embryo sexing, naturally, both male and female embryos should be stored to ensure representation of both sexes and wide genetic diversity. It is a useful conservation strategy for endangered breeds. For these species, cryobanking of embryos could be helpful in establishing founder populations with the aim of eventual reintroduction into the wild (Ptak et al., 2002). Recent advancement in cryopreservation of mammalian oocytes and embryos has almost exclusively been achieved with the new vitrification techniques and may offer new perspectives to routine alternative for breeding programmes in most domestic animal species and commercial embryology.

\section{Embryo transfer}

Embryo transfer technology is an important tool to improve livestock at faster rate as well as gives an opportunity to utilize the genetic contribution of both male and female at the same time. With the help of ET (embryo transfer) or MOET (multiple ovulation embryo transfer) techniques (Nicholas and Smith, 1983) faster improve of livestock, rapid expansion of elite animals, genetic gain, accelerated herd development and conservation of rare genetic stocks could be achieved. Embryo transfer and other associated reproductive technologies facilitate genetic improvement and have been successively used for rapidly multiplying the population of elite breeds of cattle (Thibier, 1996), buffalo (Madan el al., 1993), sheep (Holm et al., 1996), goat (Pawshe et al., 1994,), horse (Squires et al., 1999) and pig (Hazeleger and Kemp, 1999). In 2002, approximately 539680 ETs were performed worldwide, mainly in dairy cattle, with $62 \%$ being transferred in North America and Europe, $16 \%$ in South America and $11 \%$ in Asia (Madan, 2005). Moreover, the latest report of the International Embryo Transfer Society Data Retrieval Committee, 800000 embryos in cattle (Thibier, 2009), 25000 in sheep, 7000 in goat, 30000 in pig and 12000 in horses (Thibier, 2006) were transferred worldwide (two thirds as in vivo derived embryos and one third as in vitro produced) with $55-70 \%$ conception rate (Thibier, 2009).

\section{Embryo genomics}

The emerging array of new methods in biology such as differential display reverse transcriptionPolymerase chain reaction (DDRT-PCR), subtractive cDNA libraries and quantitative real time Polymerase chain reaction (RT-PCR) will significantly extend the possibilities of revealing differences in mRNA expression patterns throughout the preimplantation development. The expression pattern of specific genes critically involved in preimplantation development will aid in selecting markers for determining quality embryo and acts as a useful tool to assess the normality of the embryos and a tool to optimize the reproductive technologies. Using qualitative and quantitative RTPCR assays, expression pattern of several classes of genes have been studied in preimplantation stages of murine and bovine embryos (Niemann et al., 2000) covering more than 32 physiological functions involving the expression of about 250 different genes in the murine embryos and about its physiological functions and expression of 60-70 genes in farm animal embryos (Wrenzycki et al., 2005).

\section{Cloning}

Cloning is a powerful technique and potentially it could be used for multiplication of elite animals and minimize the genetic variation in experimental animals. It can be used for the conservation as well as propagation of endangered species. It may be used as a tool for the production of stem cells for therapeutic purposes, as therapeutic cloning. Cloning using somatic cells offers opportunities to select and multiply animals of specific merits (Das et al., 2003). Numerous types 
of somatic cells are used as donors in somatic cloning: foetal fibroblasts, adult fibroblasts, granulosa cells, hepatocytes, lymphocytes etc (Campbell et al. 2007). First animal obtained by somatic cloning was a sheep, "Dolly" (Willmut et al. 1997). Since then, SCNT was used successfully for cloning cattle (Cibelli et al., 1998), pig (Polejaeva et al., 2000), goat (Baguisi et al., 1999) and horse (Galli et al., 2003). Cloning procedure using embryonic stem cells (ESCs) is called Nuclear Transfer-derived Embryonic Stem Cell (NTESC). However, although ESCs were derived for humans and some laboratory animals, derivation of farm animal embryonic stem cells (faESCs) is still unsuccessful (Beyhan et al. 2007). The alternative to faESCs could be embryonic germ cells (EGCs) and spermatogonia stem cells (Brevini et al. 2008).

Cloning holds the promise of bypassing conventional breeding procedures to allow creation of thousands of precise duplicates of genetically engineered animals. In remote areas, where sampling and storage of adequate samples of semen and embryos is not practical, one could use clone samples from diverse animals for conservation of the available genetic diversity. The local breeds may contain valuable genes that confer adaptation, especially to heat tolerance or disease resistance, and there is an urgent need to prevent their extinction which can achieved by cloning techniques. In the future, cloning may be used in xenotransplantation, as it would allow multiplication of humanized pigs, the organs of which could be transplanted to humans (Duszewska and Reklewski 2007).

In regards to the status of cloning technique, a survey conducted in 2005 by the OIE (MacKenzie, 2005), in which 91 countries participated (60 percent from developing countries), 4 percent of the respondents in Africa and 23 percent of the respondents in Asia, reported having cloning capabilities. Recently in the list of cloned animal, first cloned camel, "Injaz", a female, (2009) and second cloned camel, Bin Soughan, a male, (2010) were born at the Camel Reproduction Center in Dubai, United Arab Emirates. Through introducing a new technique, "Hand guided Cloning Technique" world's first buffalo calf GARIMA-I (2009) was born at NDRI, Karnal (India). Later on by utilizing same technique, GARIMA-II (2009), and a male buffalo calf, Shresth (2010) have been produced in same institute.

\section{Transgenesis}

Since the initial demonstration in 1980s that a transgenic animal can be generated harboring a transgene from a different species, genetic engineering has revolutionized all aspects of fundamental biological and biomedical research. Since then much has been accomplished in the generation of various types of first transgenic animals like mouse (Gurdon and Ruddle, 1981) pig (Hammer et al., 1985) sheep (Simon et al., 1998) goat (Ebert et al., 1991) and cattle (Cibelli et al., 1998). Several biotechnological techniques viz., pro-nuclear micro-injection, cytoplasmic micro-injection, retrovirus based vectors, transferring DNA to embryos or embryonic stem cells via retroviral vectors, sperm mediated gene transfer of lentivectors and RNA interference, are presently being used to produce transgenic animals.

Transgenic farm animals can be used both in breeding and biomedicine (Robl et al., 2007; Wells, 2010). In breeding, transgenic individuals produced are equipped with disease resistance and improved quantitative and qualitative traits. For example transgenic cows producing milk of increased $\hat{a}-$ caseine and $\hat{e}$-caseine content, pigs with high body weight gain or fat to muscle tissue, expressing human growth hormone and human haemoglobin (Niemann et al. 2005), sheep with integrated keratin-IGF-I gene and higher production of wool (Kues and Niemann 2004), sheep and goat with antitrombin III and áantitripsin in milk (Kues and Niemann 2004). An important achievement was production of transgenic cows resistant to mastitis (Wall et al. 2005). There is a high interest in using transgenic farm animals as bioreactors producing human recombinant proteins in mammary gland (Kues and Niemann, 2004; Redwan, 2009). Transgenic domestic pigs are used in studies on xenotransplants, i.e. transplantation of animal body parts into humans (Niemann et al., 2005). Researches are going on for production of environment-friendly transgenic individuals or using such animals in basic studies as a model to understand various physiological processes in farm animals and humans (Niemann et al., 2005).

\section{Stem cell technology}

Stem cells are cells found in all multicellular organisms. They retain the ability to self-renew through mitotic cell division and can differentiate into a diverse range of specialized cell types. Embryonic stem cells, cord blood cells, adult or somatic stem cells and spermatogonial stem cells are the major types used for various purposes. Stem cells are having various applications like, model for developmental biology, organ transplantation, gene therapy, drug development, chimera production and in the field of regenerative 
medicines (Bajada et al., 2008). Regarding its application in farm animals reproduction, embryonic stem cells are important to provide a method to introduce precise genetic modification into animals by homologous recombination of ES cells (Lombardo et $a l ., 2007)$ followed by blastocyst injection for chimera derivation and breeding, or by somatic cell nuclear transfer. A second important application is to provide large animal models in which the ES cell technology can be tested for tissue-specific differentiation (Brown et al., 2007) and cell therapy of various tissues and organs. ES cell mediated gene transfer has some distinct advantage over other transgenic methods. First, the efficiency of producing transgenic animal could be significantly increased with this technology. Secondly, these cells can be transformed in vitro with foreign DNA (Robertson, 1991). This provides the opportunity to establish the stable incorporation of the desired gene before chimera production. For the production of chimera several lines of ES cells were obtained from (1) inner cell mass of blastocysts, (2) single blastomeres isolated from embryos at earlier stages of development, or even from (3) one-cell stage embryos (Hwang et al., 2004, Klimanskaya et al., 2006).

Spermatogonial stem cells (SSCs) transfer is commonly used in rodents to study the control of spermatogenesis with the ultimate goal to enhance or suppress the male infertility. The successful transplant of testicular tissue containing SSCs used in goat and pig is readily adapted in cattle (Honaramooz et al., 2003, Joerg et al., 2003). In cattle germ line transfer has the potential use in commercial breeding systems. By transplanting SSCs from elite bulls into lesser males followed by natural service, elite genetics could be disseminated more widely (Herrid et al., 2006). This system could create an alternative to artificial insemination for the use in elite sires in the cattle industry in areas where AI is not practicable (Hill and Dobrinski, 2006). Herrid et al. (2006) demonstrated that male germ cell transplantation between the unrelated bull calves and between cattle breeds could also be successful. Current knowledge on the biology of stem cells is limited regarding to their potential applications in various research field and farm animal reproduction but researches are going on for betterment.

\section{Nanotechnology}

Nanotechnology is recent advancement in cellular and molecular biotechnology. It has an enormous potential to revolutionize agriculture and livestock sector. This technology allows researchers to handle biological materials and media in minute quantities usually nanoliters or picoliters. In addition to its applications in cellular biology, biotechnology, theraputic medicine and genetics, it might be useful technique in farm animal breeding and reproduction. Microfluidic and nanofluidic (Schuster et al., 2003; Eijkel et al., 2005) are recent tools to simplify traditional procedures of in vitro fertilization (IVF) and in vitro embryo production (Suh et al., 2006). More recent reports have demonstrated the utility of microfluidics in isolation of motile sperm without centrifugation (Schuster et al., 2003). Oocyte manipulation under in vitro condition can also become feasible with advent of this technique (Beebe et al., 2002). Glasgow et al., (2001) first established that manipulation and movement of an embryo in a microfluidic environment. It can also be used in sorting of sperm and eggs. These systems control the flow of liquids or gases through a series of micro and nanoscale channels and valves, which is assisted with computer circuit for data analysis. Nanotechnology has its application in genome mapping and sequencing furnishes a hope to identify gene sequences that relate to commercially valuable traits such as disease resistance and leanness of meat. By including probes for these traits on biochips, breeders will be able to speedily identify elite breeders and screen out genetic diseases. In farm animal breeding heat detection can be done by implanting a nanotube (O'Connell et al., 2002) under the skin to detect the changes in the level of estradiol in the blood. The signal from this sensor will be incorporated as a part of a central monitoring and control system to actuate breeding.

\section{Conclusion}

By way of conclusion it may be stated that, after a hiatus following the introduction of artificial insemination during the 1980s, recently assisted reproduction in farm animals is receiving renewed attention. This growing interest is largely driven by the desire to breed transgenic founder animals as well as cloned animal providing substances suitable for the pharmaceutical industry. Embryo genomics are a valuable tool for studying responsible cause of various defects at cellular level (early embryonic death due to defective expression of genes etc). Now a days introduction of stem cells and Nanotechnology made acceleration to the field of assisted reproductive techniques create a hope for such animals which may contains all desired characters. In the long run, the results of these ongoing efforts will benefit the entire farm animal industry worldwide. 


\section{References}

1. Annual report, (2007-2008). Department of Animal Husbandry, Dairying \& Fisheries Ministry of Agriculture, Government of India, New Delhi.

2. Apparao, K. B. C., Pawshe, C. H. And Totey S.M. (1993). Sex determination of in vitro developed buffalo (Bubalus bubalis) embryos by DNA amplification. Molecular reproduction and development, 36: 291-296

3. Baguisi, A., Behboodi, E., Melican, D.T., Pollock, J.S., Destrempes M.M. \& Cammuso, C., (1999). Production of goats by somatic cell nuclear transfer. Nature Biotechnology, 17: 456-61.

4. Bajada, S., Mazakova, I., Richardson, B.J., \& Ashammakhi, N. (2008).Updates on stem cells and their applications in regenerative medicine. Tissue Eng. Regen. Med, 2: 169-183.

5. Barcelo-Fimbres, M \& Seidel, G.E. (2007). Effects of fetal calf serum, phenazine ethosulfate and either glucose or fructose during in vitro culture of bovine embryos on embryonic development after cryopreservation. Mol. Reprod. and Dev., 74: 13951405.

6. Beebe, D., Wheeler, M., Zeringue, H., Walters, E. \& Raty, S. (2002). Microfluidic technology for assisted reproduction. Theriogenology, 57: 125-135.

7. Beyhan Z., Iager, A.E., Cibelli J.B., (2007). Interspecies nuclear transfer: Implication for embryonic stem cell biology. Cell Stem Cell, 1: 50212.

8. Boa-Amponsem, K. \& Minozzi, G. (2006). The state of development of biotechnologies as they relate to the management of animal genetic resources and their potential application in developing countries. Background Study Paper, 33.

9. Brevini, T.A., Antonini, S., Pennarossa, G. \& Gandolfi, F. (2008). Recent progress in embryonic stem cell research and its application in domestic species. Reprod. in Domestic Animals, 43(2): 193-199.

10. Brown, B.D, Gentner, B., Cantore, A., Colleoni, S., Amendola, M., Zingale, A., Baccarini, A., Lazzari, G., Galli, C. \& Naldini, L. (2007). Endogenous microRNA can be broadly exploited to regulate transgene expression according to tissue, lineage and differentiation state. Nat. Biotechnol, 25:1457-1467.

11. Campbell, K.H., Fisher, P., Chen, W.C., Choi, I., Kelly, R.D.W., Lee, J.H. \& Xhu, J., (2007). Somatic cell nuclear transfer: Past, present and future perspectives. Theriogenology, 68: 214-231.

12. Camus, A., Clairaz, P., Ersham, A., Van Kappel, A.L., Savic, G. \& Staub, C. (2006). Principe de la vitrification: cine'tiques comparatives. The comparison of the process of five different vitrification devices. Gynecologie, Obstetrique \&
Fertilite, 34: 737-745.

13. Catt, S.L., Catt, J. W., Gomez, M.C., Maxwell, W.M.C. \& Evans, G. (1996). Birth of a male lamb derived from an in vitro matured oocytes fertilized by intra cytoplasmic injection of single presumptive male sperm. Vet. Rec., 16: 494-495.

14. Chen, S.U., Lien, Y.R., Chen, H.F., Chang, L.J., Tsai, Y.Y., \& Yang, Y.S. (2005). Observational clinical follow-up of oocyte cryopreservation using a slowfreezing method with 1,2-propanediol plus sucrose followed by ICSI. Human Reproduction, 20:19751980.

15. Cibelli, J.B., Stice, S.L., Golueke, P.J., Kane, J.J., Jerry, J., Blackwell, C., Ponce De Leon, F.A. \& Robl, J.M. (1998). Cloned transgenic calves produced from nonquiescent fetal fibroblasts. Science, 280: 12561258.

16. Colleoni, S., Barbacini, S., Necchi, D., Duchi, R., Lazzari, G. \& Galli, C. (2007). Application of ovum pick-up, intracytoplasmic sperm injection and embryo culture in equine practice. Proceedings of American Association of Equine Practitioners, 53: 554-559.

17. Das, S.K., Majumdar, A.C., \& Sharma, G.T. (2003). In vitro development of reconstructed goat oocyte after somatic cell nuclear transfer with fetal fibroblast cells. Small Rumin. Res., 48: 217-225.

18. De Graaf, S., Evans, G., Maxwell, W., Cran, D. \& O'Brien, J. (2007). Birth of offspring of predetermined sex after artificial insemination of frozenthawed, sex-sorted and re-frozen-thawed ram spermatozoa. Theriogenology, 67:391-398.

19. Duszewska, A.M. \& Reklewski, Z. (2007). Uzyskiwanie zarodków zwierz ${ }^{1}$ gospodarskich in vitro (Obtaining in vitro embryos from farm animals). In Polish, summary in English. Medycyna Weterynaryjna, 63: 1522-1525.

20. Ebert, K.M., Selgrath, J.P., Di Tullio, P., Smith, T.E., Memon, M.A.,Vitole, J.A., \& Gordan, K. (1991). Transgenic production of variant human tissue type plasminogen activator in goat milk: Generation of transgenic goat and analysis of expression. Biotechnology, 9: 835-838.

21. Eijkel, T.C.J. \& Berg, D.V.A. (2005). Nanofluidics: what is it and what can we expect from it? Microfluid Nanofluid, 1: 249-267.

22. Gajda, B. \& Smor ${ }^{1}$ g, Z. (2009). Oocytes and embryos cryopreservation-state of art and recent development in domestic animals. Journal of Animal and Feed Sciences, 18: 371-387.

23. Galli, C., Lagutina, I., Crotti, G., Colleoni, S., Turini, P., Ponderato, N., Duchi, R. \& Lazzari, G. (2003) Pregnancy: a cloned horse born to its dam twin. Nature, 424: 635-636.

24. Galli, C. \& Lazzari, G. (2008). The manipulation of gametes and embryos in farm animals. Reprod. in Domestic Animals, 43: 1-7.

25. Garner, D. \& Seidel G.J. (2008). History of 
commercializing sexed semen for cattle. Theriogenology, 69: 886-95.

26. Garner, D.L. (2006). Flow cytometric sexing of mammalian sperm. Theriogenology, 65: 943-957.

27. Glasgow, I., Zeringue, H., Beebe, D., Choi, S., Lyman, J. \& Chan, N. (2001). Handling individual mammalian embryos using microfluidics. IEEE Trans. Biomed. Eng., 48: 570-578.

28. Grossfeld, R., Klinc, P., Sieg, B. \& Rath. D. (2005). Production of piglets with sexed semen employing a non-surgical insemination technique. Theriogenology, $63 ; 2269-77$.

29. Gurdon, J.W. \& Ruddle, F.H. (1981). Integration and stable germline transmission genes injected into mouse pronuclei. Science, 214: 1244-1246.

30. Hammer, R.E., Pursel, V.G., Rexroad, C., Wall, R.J., Bolt, D.J., Ebert, K.M., Palmiter, R.D. \& Brinster R.L. (1985). Production of transgenic rabbits, sheep and pigs by microinjection. Nature, 315: 680-683.

31. Hazeleger, W \& Kemp, B. (1999). State of Art in Pig Embryo Transfer. Theriogenology, 51: 81-90.

32. Herrid, M., Vignarajan, S., Davey, R., Dobrinski, I. \& Jonathan, R.H. (2006). Successful transplantation of cells into hetrologous recipient. Reproduction, 132: 617-624.

33. Hill, J.R. \& Dobrinski, I. (2006). Male germ cells transplantation in livestock. Reprod. Fertility and Dev., 18: 13-18.

34. Hochi, S., Ito, K., Hirabayashi, M., Ueda, M., Kimura, K. \& Hanada, A. (2000). Effect of nuclear stages during IVM on the survival of vitrifiedwarmed bovine oocytes. Theriogenology, 49: 787796.

35. Holm, P., Walker W.H. \& Seamark, R.F., (1996). Embryo viability, duration of gestation and birth weight in sheep after transfer of in vitro matured and in vitro fertilized zygotes cultured in vitro or in vivo. Reprod. Fert. 107: 175-181.

36. Honaramooz, A., Behboodi, E., Blash, S., Megee S.O. \& Dobrinski, I. (2003). Germ cell transplantation in goat. Mol. Reprod. Devel., 64: 422-428.

37. Horiuchi, T.C., Emuta, Y., Yamauchi, T., Oikawa, T., Numabe \& Yanagimachi, R. (2002). Birth of normal calves after intracytoplasmic sperm injection of bovine oocytes: A methodological approach. Theriogenology, 57: 1013-1024.

38. Huang, W.T. \& Holtz, W. (2002). Effect of meiotic stages, cryoprotetants, cooling and vitrification on cryopreservation of porcine oocytes. Asian Aust. J.Anim. Sci., 15: 485-493.

39. Hurt, A.E., Landim-Alvarenga, G.E., Siedel, J.R. \& Squires, E.L. (2000). Vitrification of immature and marure equine and bovine oocytes in ethylene glycol, ficoll and sucrose solution using open-pulled straws. Theriogenology, 54: 119-128.

40. Hwang, W.S., Ryu, Y.J., Park, J.H., Park, E.S., Lee, E.G., Koo, J.M., Jeon H.Y., Lee B.C., Kang S.K., Kim S.J., Ahn C., Hwang J.H., Park K.Y., Cibelli J.B. \&
Moon S.Y., (2004). Evidence of a pluripotent human embryonic stem cell line derived from a cloned blastocyst. Science, 303: 1669-1674.

41. Ivanoff, E. I. (1922). On the use of artificial insemination for zootechnical purposes in Russia. Agric. Sci., 12: 244-256.

42. Joerg, H., Janett, F., Muller, S., Graphodatskaya, D., Suwattana, D., Asai, M. \& Sranzinger G. (2003). Germ cell transplantation in a klienefelter bull. Biol. of Reprod. 69:1940-1944.

43. Klimanskaya, I., Chung, Y., Beckers, S., Lu, S.J. \& Lanza, R. (2006). Human embryonic stem cell lines derived from single blastomeres. Nature, 444: 481 485.

44. Kues, W.A. \& Niemann, H., (2004). The contribution of farm animals to human health. Trends of Biotechnology, 22 (6): 286-294.

45. Larman, M.G. \& Gardner D.K. (2010). Vitrifying mouse oocytes and embryos with super-cooled air. Human Reproduction, 25: 265.

46. Lopatarova, M., S., Cech, P., Krontorad, L., Holy, J., Hlavicova \& Dolezel, R. (2008). Sex determination in bisected bovine embryos and conception rate after the transfer of female demi-embryos. Vet. Med., 53: 295603.

47. Luz, M.R., Holanda, C.C., Pereira, J.J., Teixeira N.S., Vantini, R., Freitas, P.M.C., Salgado, A.E.P., Oliveira, S.B., Guaitolini, C.R.F. \& Santos, M.C. (2009). Survival rate and in vitro development of in vivo produced and cryopreserved dog embryos. Reproduction, Fertility, and Development, 22: 208209.

48. MacKenzie, A.A., (2005). Applications of genetic engineering for livestock and biotechnology products, Technical Item II, 73rd General Session, Paris, International Committee, OIE.

49. Madan, M.L., Prakash, B.S., Jailkhani, S., Singla, S.K., Palta, P. \& Manik, R.S. (1993). Buffalo endocrinology with special reference to embryo transfer. Pub. 265, Natinal dairy research institute, Karnal, India.

50. Madan, M.L. (2005). Animal biotechnology: applications and economic implications in developing countries. Rev. sci. tech. Off. Int. Epiz. 24(1): 127-139.

51. Martin, M.J. (2000). Development of in-vivo matured porcine oocytes following intracytoplasmic sperm injection. Biol. Reprod., 63: 109-112.

52. Muthukumar, K., Mangalaraj, A.M, Kamath, M.S. \& George, K. (2008). Blastocyst cryopreservation: vitrification or slow freeze. Fertility and Sterility, 90: 426-427.

53. Nicholas, F. W. \& Smith, C. (1983). Increased rates of genetic change in dairy cattle by embryo transfer and splitting. Anim. Prod., 36:341.

54. Niemann, H., Kues, W. \& Carnwath J.W. (2005).Transgenic farm animals: present and future. Revue Scientifique et Technique (International Office 
of Epizootics), 24: 285-298.

55. Niemann H. \& Wrenzycki C. (2000). Alterations of expression of developmentally important genes in preimplantation bovine embryos by in vitro culture conditions: implications for subsequent development. Theriogenology, 53:21-34.

56. O'Connell, M.J., Bachilo, M.S., Huffman, B.C, Moore, C.V, Strano, S. M. \& Smalley, R.E. (2002). Band Gap Fluorescence from Individual SingleWalled Carbon Nanotubes. Science, 297: 593-596.

57. Park, K.W., Lai, L., Cheong, H.T., Cabot, R., Sun, Q.Y., Wu, G., Rucker, E.B., Durtschi, D., Bonk A., Samuel, M., Rieke, A., Day, B.N., Murphy, C.N., Carter, D.B., Prather, R.S., (2002). Mosaic gene expression in nuclear transfer-derived embryos and the production of cloned transgenic pigs from earderived fibroblasts. Biol. of Reprod., 66: 1001-1005.

58. Parrilla, I., Vazquez, J., Roca, J. \& Martinez E. (2004). Flow cytometry identification of $\mathrm{X}$ - and Ychromosome-bearing goat spermatozoa. Reprod. Domest. Anim., 39: 58-60.

59. Pawshe, C.H., Totey, S.M. \& Jain, S.K. (1994). Acomparison of three methods of recovery of goat oocytes for in vitro maturation and fertilization. Theriogenology, 42: 117-125.

60. Petyim, S., Makemahar, O., Kunathikom, S., Choavaratana, R., Laokirkkiat, P. \& Penparkkul, K. (2009). The successful pregnancy and birth of a healthy baby after human blastocyst vitrification using Cryo-E, first case in Siriraj Hospital. Journal of the Medical Association of Thailand, 92: 1116-1121.

61. Plummer, W.E. \& Beckett, D. (2006). Development of successful sex determination method of bovine embryos utilizing embryo biopsy and pcr. California State University Agricultural Research Initiative Final Report.

62. Polejaeva, I.A., Chen, S.H., Vaught T.D., Page, R.L., Mullins, J., Ball, S., Dai, Y., Boone, J., Walker, S., Ayares, D.L., Colman, A. \& Campbell, K.H., (2000). Cloned pigs produced by nuclear transfer from adult somatic cells. Nature 407: 86-90.

63. Polge, C., Smith, A.U. \& Parkes, A.S. (1949). Revival of spermatozoa after vitrification and dehydration at low temperatures. Nature, 164, 666.

64. Portmann, M., Nagy, Z.P. \& Behr, B. (2010). Evaluation of blastocyst survival following vitrification/warming using two different closed carrier systems. Human Reproduction, 25: i261.

65. Rall, W.F. \& Fahy, G.M. (1985). Ice-free cryopreservation of mouse embryos at $-196{ }^{\circ} \mathrm{C}$ by vitrification. Nature, 313:573-575.

66. Redwan, E.L. (2009). Animal-derived pharmaceutical proteins. Journal of Immunoassay \& Immunochemistry, 30(3): 262-290.

67. Robl, J.M., Wang, Z., Kasinathan, P. \& Kuroiwa Y. (2007). Transgenic animal production and animal biotechnology. Theriogenology, 67: 127-133.

68. Schuster, T., Cho, B., Keller, L., Takayama, S. \&
Smith, G. (2003). Isolation of motile sperm from semen samples using microfluidics. Reprod. Biomed., 7: 73-79.

69. Seidel, G.J., Schenk, J., Herickhoff, L., Doyle, S., Brink, Z. (1999). Insemination of heifers with sexed sperm. Theriogenology, 52: 1407-20.

70. Sharma, G. Taru, \& Loganathasamy, K. (2006). Effect of meiotic stages during in vitro maturation on the survival of vitrified-thawed buffalo oocytes. Veterinary Research Communication, 1-13.

71. Simon, J.P., Wilmut, I., Clark, A.J., Archibald, A.L., Bishop, J.O., \& Lathe, K. (1998). Gene transfer into sheep. Biotechnology, 6: 179-183.

72. Sirard, M.A., Richard, F., Blondin, P. \& Robert, C. (2006). Contribution of the oocyte to embryo quality. Theriogenology, 65: 126-136.

73. Spallanzani, L. (1784). Dissertations relative to the natural history of animals and vegetables. Trans. by $\mathrm{T}$. Beddoes in Dissertations Relative to the Natural History of Animals and Vegetables. J. Murray, London, 2:195-199.

74. Squires, E.L., McCue, P.M. \& Vanderwall, D. (1999). The current status of equine embryo transfer. Theriogenology, 51:91-104.

75. Sugiyama, R., Nakagawa, K., Shirai, A., Sugiyama, R., Nishi, Y., Kuribayashi, Y. \& Inoue, M. (2010). Clinical outcomes resulting from the transfer of vitrified human embryos using a new device for cryopreservation (plastic blade). Journal of Assisted Reproduction and Genetics, 27: 161-167.

76. Suh, R., Phadke, N., Ohl, D., Takayama, S. \& Smith, G. (2006). In vitro fertilization within microchannels requires lower total numbers and lower concentrations of spermatozoa. Hum. Reprod. 21: 477-483.

77. Sun, X., Li, Z., Yi, Y., Chen, J., Leno, G.H. \& Engelhardt, J.F. (2008). Efficient term development of vitrified ferret embryos using a novel pipette chamber technique. Biology of Reproduction, 79: 832-840.

78. Thibier, M. (1996). Statistics of the ET industry around the world. IETS Newsletter 15(4): 10-13.

79. Thibier, M. (2009). The worldwide statistics of embryo transfer in farm animals. Embryo transfer Newsletter, 27(4): 13-19.

80. Tsang, W.H. \& Chow, K.L. (2009). Mouse embryo cryopreservation utilizing a novel high-capacity vitrification spatula. Bio. Techniques, 46: 550-552.

81. Uehera, T. \& Yanagimachi, R. (1976). Microsurgical injection of spermatozoa into hamster eggs with subsequent transformation of sperm nuclei into male pronuclei. Biol. Reprod. 15: 467-470.

82. Vajta, G., Holm, P., Greve, T. \& Callesen, H. (1996). Overall efficiency of in vitro embryo production and vitrification in cattle. Theriogenology, 45: 683-689.

83. Wall, R.J., Powell, A.M., Paape, M.J., Kerr, D.E., Bannerman, D.D., Pursel, V.G., Wells, K.D., Talbot, N. \& Hawk, H.W. (2005). Genetically enhanced cows resist intra-mammary Staphylococcus 
aureus infection. Nature Biotechnology, 23(4): 445-451.

84. Wells, D.J. (2010). Genetically modified animals and pharmacological research. Handbook of Experimental Pharmacology, 199, 213-26.

85. Wrenzycki, C., Herrmann, D., Hahn, A.L, Gebert, C., Korsawe, K., Lemme, E., Joseph, W., Carnwath \& Niemann, H. (2005). Epigenetic reprogramming throughout preimplantation development and consequences for assisted reproductive technologies.
Embryo Today, 75(1): 1-9.

86. Yavin, S., Aroyo, A., Roth, Z. \& Arav, A. (2009). Embryo cryopreservation in the presence of low concentration of vitrification solution with sealed pulled straws in liquid nitrogen slush. Human Reproduction, 24: 797-804.

87. Zoheir, K.M.A. \& Allam, A.A. (2010). A rapid method for sexing the bovine embryo. Anim. Repro. Sci., 119: 92-96. 